\title{
PERANAN PEMERINTAH DAERAH DALAM UPAYA PENANGGULANGAN EKSPLOITASI TERHADAP ANAK DI KOTA BENGKULU BERDASARKAN UNDANG-UNDANG NOMOR 23 TAHUN 2002 TENTANG PERLINDUNGAN ANAK
}

\author{
Riri Tri Mayasari \\ Fakultas Hukum Universitas Muhammadiyah Bengkulu \\ Jalan Adam Malik, km 9, Kota Bengkulu \\ Pos-el: riri.mayasari86@umb.ac.id \\ Mikho Ardinata \\ Fakultas Hukum Universitas Muhammadiyah Bengkulu \\ Jalan Adam Malik, km 9, Kota Bengkulu \\ Pos-el: mikhoardinata@umb.ac.id
}

\begin{abstract}
The problem of child exploitation is considered widespread in the community because there are many children employed as road workers. There are no age restrictions for families whose economy is insufficient to employ their children to support the economy. Bengkulu City is one of the areas where there are child problems that are quite worrying. The number of street children in Bengkulu City on highways such as Simpang Lima, Simpang Jam and other locations shows that there are problems in the lives of children in Bengkulu City, efforts by the local government to overcome the crime of child exploitation in the city of Bengkulu. The government is responsible for providing free education and / or support or special services to children from disadvantaged families, neglected children and children in remote areas.
\end{abstract}

Keywords: local government; child exploitation

\begin{abstract}
Abstrak: Masalah ekspoitasi anak ini dirasa sudah biasa untuk kalangan masyarakat,karena sudah banyak anakanak yang diperkerjakan sebagai pekerja jalanan, tidak adabatasan umur yang membuat keluarga yang perekonomiannya kurang mencukupi berlomba-lomba memperkerjakan anak mereka agar dapat membantu perekonomian. Kota Bengkulu termasuk salah satu wilayah yang mempunyai permasalahan anak yang cukup mengkhawatirkan. Banyaknya anak jalanan di Kota Bengkulu yang ada di jalan raya seperti Simpang Lima, Simpang Jam dan tempat-tempat lainnya menunjukkan bahwa ada permasalahan dalam kehidupan anak di Kota Bengkulu, Bagaimana upaya pemerintah daerah dalam menanggulangi eksploitasi terhadap anak dikota bengkulu tujuan penelitian ini adalah untuk mengetahui upaya pemerintah daerah dalam menanggulangi kejahatan eksploitasi anak dikota bengkulu.pemerintah bertanggung jawab untuk memberikan biaya pendidikan dan/atau bantuan Cuma-Cuma atau pelayanan khusus bagi anak dari keluarga tidak mampu, anak terlantar, dan anak yang bertempat tinggal di daerah terpencil.
\end{abstract}

Kata Kunci : Pemerintah Daerah; Eksploitasi Anak 


\section{Pendahuluan}

Anak adalah anugerah Tuhan yang Maha Esa, Setiap anak memiliki hak asasi atau hak dasar sejak dilahirkan, sehingga orang lain tidak boleh merampas hak-hak anak seperti yang tercantum dalam Undang-Undang Perlindungan anak nomor 23 Tahun 2002 Bab III Pasal 4 sampai pasal 19 tentang hak anak. Seharusnya Negara menjamin kesejahteraan tiap-tiap warga negaranya, termasuk perlindungan terhadap anak yang merupakan hak asasi manusia. Arti dari anak dalam penjelasan atas UndangUndang Republik Indonesia Tahun 35 Tahun 2014 tentang perubahan atas Undang-Undang 23 Tahun 2002, Tentang Perlindungan anak yang menyebutkan bahwa anak adalah amanah sekaligus karunia dari Tuhan Yang Maha Esa yang senantiasa harus dijaga karena dalam dirinya melekat harkat, martabat, dan hakhak sebagai manusia yang harus dijunjung tinggi. ${ }^{1}$

Perlindungan anak terkait erat dengan lima pilar yakni, orang tua, keluarga, masyarakat, pemerintah, pemerintah daerah dan negara. Kelimanya memiliki keterkaitan satu sama lain sebagai penyelenggara perlindungan anak.

${ }^{1}$ Ketentuan Umum Pasal 1 Dan 2 UndangUndang 23 Tahun 2002 Tentang Perlindungan Anak, n.d.
Dalam bentuknya yang paling sederhana, perlindungan anak mengupayakan agar setiap hak anak tidak dirugikan. Perlindungan anak bersifat melengkapi hak-hak lainnya menjamin bahwa anak-anak akan menerima apa yang mereka butuhkan agar mereka dapat bertahan hidup, berkembang dan tumbuh. ${ }^{2}$

Pada dasarnya perlidungan anak bertujuan untuk menjamin terpenuhinya hak-hak anak seperti yang diatur dalam konvensi anak dalam kententuan pada pasal 13 ayat (1)Undang-Undang Nomor 23 Tahun 2002 tentang perlindungan Anak yaitu $^{3}$

"Setiap anak selama dalam pengasuhan orangtua, wali, atau pihak lain mana pun yang bertanggung jawab atau pengasuhan, berhak mendapat perlindungan dari perlakuan :
a. Diskriminasi
b. Ekploitasi, baik ekonomi maupun seksual
c. Penelantaran
d. Kekejaman , kekerasaan, dan penganiayaan
1). Ketidakadilan
2). Perlakuan salah lainya
Masalah ekspoitasi anak ini dirasa sudah biasa untuk kalangan masyarakat, karena sudah banyak anak-anak yang diperkerjakan sebagai pekerja jalanan, tidak ada batasan umur yang membuat

${ }^{2}$ Rini Fitriani, “Anak Dalam Melindungi Dan Memenuhi Hak-Hak Anak," Jurnal Hukum: Samudra Keadilan 11, no. 2 (2016):, h. 250-258.

${ }^{3}$ Zulkhair Soeaidy, Sholeh, Dasar Hukum Perlindungan Anak (Jakarta: Novindo Pustaka Mandiri, 2001), h. 8. 
keluarga yang perekonomiannya kurang mencukupi berlomba-lomba memperkerjakan anak mereka agar dapat membantu perekonomian. Banyak anakanak menerjuni bursa kerja karena tidak tersedianya sekolah, jumlahnya tidak cukup, atau mahal. Kemiskinan, kurangnya kesempatan memperoleh pendidikan, dibarengi dengan lemahnya perlindungan hukum serta tidak adanya pelaksanaan undang-undang yang efektif, menyebabkan permasalahan menjadi semakin berat. ${ }^{4}$

Hak anak sebagaimana diabadikan dalam konvensi adalah hak anak-anak atas asuhan dari orang tua mereka sendiri, wajib belajar, dan pendidikan dasar yang cuma-cuma, pencapaian standar kesehatan tinggi, jaminan sosial dan ketentuan untuk istirahat dan rekreasi. Jika anak terpaksa atau harus bekerja, maka berarti bisa menempatkan anak-anak tersebut dalam kategori berbahaya dan memengaruhi proses tumbuh kembang anak secara wajar, ini menjadi sebuah permasalahan yang serius .

Menurut Bellamy, jika anak-anak bekerja di usia dini (yang biasanya berasal keluarga miskin dengan pendidikan yang terabaikan) sesungguhnya akan melestarikan kemiskinan, karena anak yang bekerja umumnya akan tumbuh menjadi orang dewasa yang terjebak

\footnotetext{
${ }^{4}$ Hadi Setia Tunggal, Konvensi Hak-Hak Anak (Convention on the Rights of the Child), cetakan ke. (Harvarindo, 2000).
}

dalam pekerjaan yang tak terlatih dan dengan upah yang sangat buruk. ${ }^{5}$ Bentuk eksploitasi anak dan juga hak anak yang terancam membutuhkan peran aktif baik dari orang tua, keluarga, maupun sebagai masyarakat wajib memberikan perlindungan kepada mereka sesuai dengan Undang-Undang Perlindungan Anak No. 23 Tahun 2002 Pasal 20 menyatakan “ Negara, pemerintah, masyarakat, keluarga, dan orangtua berkewajiban dan bertanggungjawab terhadap penyelenggaraan perlindungan anak."6

Di kota Bengkulu pada saat sekarang ini setiap persimpangan terdapat anak-anak yang berusia antara 5-18 Tahun dan anak-anak tersebut mengamen dan mengharapkan belas kasihan oleh pengendara roda dua maupun roda empat dan terkesan dilakukan pembiaraan. Beberapa anak dijalan mengatakan bahwa mereka bekerja berdasarkan keinginan sendiri tetapi walaupun mereka mengatakan demikian selaku orang tua, masyarakat, maupun pemerintah daerah telah melakukan pembiaraan dengan mengabaikan hak-hak anak bahwa kita ketahui anak juga mempunyai hak dan kewajiban sebagai anak, dan hak anak tersebut antara lain setiap anak berhak

5 Nachorowi Djajal Hardius Usman, Pekerjaan Anak Di Indonesia (Jakarta: Grasindo, 2004), h. 10.

${ }^{6}$ Siti Nurbayani K Ajeng Gayatri Octorani Putri, Elly Malihah, "Ekploitasi Pekerja Anak Dibawah Umur Sebagai Bentuk Penyimpangan Sosial," Jurnal Sosietas Volume 5, no. No 1 (2002). 
Riri Tri Mayasari dan Mikho Ardinata:

Peranan Pemerintah Daerah Dalam Upaya Penanggulangan Eksploitasi Terhadap Anak Di Kota Bengkulu Berdasarkan Undang-Undang Nomor 23 Tahun 2002 Tentang Perlindungan Anak

untuk dapat hidup, tumbuh, berkembang, dan berispirasi secara wajar sesuai dengan harkat dan martabat kemanusiaan, serta mendapat perlindungan dari kekerasan dan diskriminasi, setiap anak berhak atas suatu nama sebagai identitas diri dan status kewarganegaraan dan anak juga berhak beribadah menurut agamanya, berpikir, dan berekspresi sesuai dengan tingkat kecerdasan dan usianya, dalam bimbingan orang tua, anak juga berhak menyatakan dan didengarkan pendapatnya, menerima, mencari, dan memberikan informasi sesuai dengan kecerdasan dan usianya. $^{7}$

Hal ini menjadi perhatian yang serius karena kurangnya perhatian dari pemerintah Kota bengkulu dalam menanggulangi upaya eksploitasi terhadap anak sehingga dalam hal ini pemerintah kota bengkulu sesuai dengan amanat UUD 1945. Memberikan perlindungan yang sudah diatur dalam UUD NKRI tahu 1945 Pasal 34 ayat (1) bahwa "Fakir miskin dan anak terlantar dipelihara oleh negara".Artinya pemerintah mempunyai tanggung jawab terhadap pemeliharaan dan pembinaan anak. Tujuan penelitian ini adalah untuk mengetahui upaya pemerintah daerah dalam menanggulangi eksploitasi terhadap anak dikota bengkulu.

7 Megalia Tifani Piri, "Perlindungan Hukum Terhadap Tindakan Eksploitasi Anak (Kajian Undang-Undang Nomor 23 Tahun 2002," Lex Administratum Vol.I, no. No.2,Apr-Jun (2013).
Berdasarkan hal latar belakang tersebut peneliti tertarik meneliti mengenai eksploitasi anak dengan judul "Peranan Pemerintah Daerah Dalam Upaya Penanggulangan Eksploitasi Terhadap Anak Di Kota Bengkulu Berdasarkan Undang-Undang Nomor 23 Tahun 2002 Tentang Perlindungan Anak"

\section{A. Permasalahan}

Bagaimana upaya pemerintah daerah dalam menanggulangi eksploitasi terhadap anak dikota bengkulu berdasarkan Undang-Undang Nomor 23 Tahun 2002 Tentang Perlindungan Anak .

\section{B. Metode Penelitian}

\section{Jenis Penelitian}

Untuk mendapatkan data guna menguraikan tanggung jawab negara terhadap Jaminan Kesehatan dalam persepektif hukum hak asasi manusia maka jenis penelitian yang penulis gunakan dalam penelitian ini adalah metode penelitian hukum normatif.

Dalam melakukan penelitian hukum normatif yang disebut juga penelitian hukum yang doctrinal biasanya hanya dipergunakan sumber-sumber data sekunder saja yaitu peraturan-peraturan perundangundangan, keputusan-keputusan pengadilan teori-teori hukum dan pendapat-pendapat para sarjana hukum termuka sedangkan analisa 
yang dilakukan berupa analisa normatif-kualitatif. $^{\mathbf{8}}$

Metode penelitan merupakan bagian dari ilmu pengetahuan yang mempelajari bagaimana prosedur kerja mencari kebenaran. Metode penelian itu sendiri mempelajari tentang metoda-metoda penelitian, ilmu tentang alat-alat dalam penelitian. $^{9}$

Menurut Soerjono Soekanto, penelitian normatif atau penelitian kepustakaan adalah penelitian hukum yang dilakukan dengan cara meneliti bahan pustaka atau data sekunder belaka. Penelitian hukum normatif untuk memahami adanya hubungan antara ilmu-ilmu hukum dengan hukum positif. ${ }^{10}$

Penelitian hukum normatif merupakan penelitian kepustakaan (library research), yaitu penelitian terhadap data sekunder. Dimana data sekunder tersebuat dibagi menjadi data sekunder umum dan data sekunder di bidang hukum. ${ }^{11}$ Metode ini bertujuan untuk mengumpulkan

8 Ronny Hanitijo Soemitro, Metode Penelitian Hukum (Semarang: Ghalia Indonesia, 1983), 9.

9 Noeng Muhadjir, Metode Penelitian Kualitatif Edi IV (Yogyakarta: Rake Sarasin, 2000), h. 5-6.

${ }^{10}$ Soerjono Soekanto Dkk, Penelitian Hukum Normatif: Suatu Tinjauan Singkat (Jakarta: Raja Grafindo Persada, 2012), h. 13-14.

${ }^{11}$ Ronny Hanitijo Soemitro, Metode Penelitian Hukum Dan Jurimetri Cetakan Ketiga (Semarang: Ghalia Indonesia, 1988), $11 .$. data dan informasi dengan bantuan bermacam-macam buku, majalah hukum, artikel hukum, dan dokumen-dokumen lainnya.

\section{Sumber Bahan Hukum}

\section{a. Bahan Hukum Primer}

Bahan hukum primer merupakan bahan hukum yang bersifat autoratif artinya mempunyai otoritas. ${ }^{12}$ Bahan hukum primer dalam penelitian ini terdiri dari peraturan-peraturan tentang jaminan kesehatan dan peraturan lain terkait, yaitu:

a) Undang-Undang Dasar 1945

b) Undang-undang nomor 23 tahun 2002 tentang perlindungan anak

c) Perda nomor 5 tahun 2016 tentang penyelenggara perlindungan anak

d) Perwal nomor 06 tahun 2019 Tentang Ketentuan dan tata cara pelaksanaan peraturan daerah kota bengkulu nomor 05 tahun 2016 tentang penyelenggaraan perlindungan anak.

\section{b. Bahan Hukum Sekunder}

Bahan Hukum Sekunder dalam penelitian ini yaitu bahan hukum yang memberikan

${ }^{12}$ Peter Mahmud Marzuki, Penelitian Hukum (Jakarta: Kencana, 2005), 141.. 
Riri Tri Mayasari dan Mikho Ardinata: Peranan Pemerintah Daerah Dalam Upaya Penanggulangan Eksploitasi Terhadap Anak Di Kota Bengkulu Berdasarkan Undang-Undang Nomor 23 Tahun 2002 Tentang Perlindungan Anak

penjelasan mengenai bahan hukum primer, antara lain :

1. Pendapat para ahli yang berkaitan dengan judul penelitian;

2. Buku bacaan yang berkaitan dengan judul penelitian; dan

3. Hasil penelitian dan unsurunsur literatur lain yang relevan

\section{Prosedur Pengumpulan Bahan}

\section{Hukum}

Prosedur yang digunakan penulis berupa metode studi kepustakaan dan metode dokumentasi. Metode studi kepustakaan yaitu mengambil data dari literatur yang digunakan untuk mencari konsep, teori-teori, pendapat-pendapat, maupun penemuan yang berhubungan erat dengan pokok permasalahan penelitian ini. ${ }^{13} \quad$ Metode dokumentasi merupakan salah satu cara pengumpulan data yang digunakan peneliti untuk menginventarisir catatan, transkrip buku, atau lain-lain yang berhubungan dengan penelitian ini. Dokumen dapat digunakan karena merupakan sumber yang stabil, kaya dan mendorong.

Penelusuran literatur hukum dan informasi lainnya dilakukan dengan penelusuran off line (bukubuku) dan on line (internet). Bahan pustaka off line dapat diperoleh dari koleksi pribadi dan perpustakaan yang berupa buku, jurnal hukum dan lain-lain, sedangkan bahan pustaka on line dapat diperoleh dengan menggunakan akses internet.

\section{Analisis Bahan Hukum}

Setelah semua bahan hukum terkumpul kemudian dilanjutkan dengan pengelolaan, pengeditan, dan analisis bahan hukum. Pengelolaan bahan hukum dengan cara meringkas dan mengulas bahan-bahan tersebut, Pengelolaan bahan hukum dilakukan dengan cara mengedit (editing) data. Mengedit data adalah kegiatan memeriksa bahan-bahan yang telah dikumpulkan. ${ }^{14}$

Analisis bahan-bahan yang telah dikumpul dilakukan dengan menggunakan metode kualitatif. Pendekatan kualitatif, yaitu dengan
${ }^{13}$ Dkk, Penelitian Hukum Normatif: Suatu Tinjauan Singkat, 55.
${ }^{14}$ Sarafiah Faisal, Format-Format Penelitian Sosial (Bandung: Raja Grafindo Perkasa, 1999), h. 33. 


memusatkan perhatian pada
prinsip-prinsip umum yang
mendasari perwujudan satuan-
satuan gejala dalam kehidupan
manusia. ${ }^{15}$

Analisis bahan hukum yang dilakukan secara kualitatif untuk penarikan kesimpulan-kesimpulan tersebut, tidak hanya bertujuan mengetahui Peranan Pemerintah Daerah Dalam Upaya Penanggulangan Eksploitasi Terhada Anak di Kota Bengkulu. Manusia, tetapi juga bertujuan untuk memahami kendala-kendala yang timbul dalam pelaksanaan.

\section{Pembahasan}

Pengertian anak menurut UUD 1945 dijabarkan sebagai berikut "Ketentuan UUD 1945, ditegaskan pengaturan dengan UU No. 4 Tahun 1979 tentang Kesejahteraan Anak" yang berarti makna anak (pengertian tentang anak), yaitu seorang anak harus memperoleh hak-hak yang kemudian hak-hak tersebut dapat menjamin pertumbuhan dan perkembangan dengan wajar baik secara rohani, jasmania maupun sosial atau anak juga berhak atas pelayanan untuk mengembangkan

15 Burhan Ashshofa, Metode Penelitian Hukum (Jakarta: Rineka Cipta, 2004), h. 20. kemampuan dan kehidupan sosial. $^{16}$

Perlindungan anak merupakan suatu usaha untuk mewujudkan keadilan dalam suatu masyarakat, dengan demikian maka perlindungan anak harus di sesuaikan dalam berbagai bidang kehidupan bernegara dan bermasyarakat. ${ }^{17}$

Ketentuan perlindungan anak di dalam konstitusi, hak-hak anak merupakan bagian dari hak asasi manusia yang termuat dalam Pasal 28B ayat (2) Undang-Undang Dasar Negara Republik Indonesia Tahun 1945 (UUD NRI Tahun 1945) yang menyatakan bahwa setiap anak berhak atas kelangsungan hidup, tumbuh, dan berkembang serta berhak atas perlindungan dari kekerasan dan diskriminasi. Penyelenggaraan perlindungan anak berasaskan Pancasila dan berlandaskan UUD NRI Tahun 1945 serta prinsipprinsip dasar Konvensi Hak-hak Anak (KHA) meliputi, asas non diskriminasi, asas kepentingan yang terbaik bagi anak, asas hak

\footnotetext{
${ }^{16}$ Soemitro. Irma Setyowati, Aspek Hukum Perlindungan Anak (Jakarta: Bumi Aksara, n.d.).

17 Hendi Sastra Putra, "Peranan Rumah Singgah Al Maun Dalam Memberikan Pendampingan Anak Terlantar Di Kota Bengkulu," Jurnal Pemerintahan dan Politik Islam Volume 5 , no. Nomor`1 (2020): h. 22.
} 
Riri Tri Mayasari dan Mikho Ardinata:

Peranan Pemerintah Daerah Dalam Upaya Penanggulangan Eksploitasi Terhadap Anak Di Kota Bengkulu Berdasarkan Undang-Undang Nomor 23 Tahun 2002 Tentang Perlindungan Anak

untuk hidup, kelangsungan hidup dan perkembangan, dan asas penghargaan terhadap pendapat anak. $^{18}$

Lebih lanjut dikatakan bahwa anak adalah tunas, potensi dan generasi muda penerus cita-cita pejuang bangsa, memiliki peran strategis dan mempunyai ciri dan sifat khusus yang menjamin kelangsungan eksistensi bangsa dan negara pada masa depan. ${ }^{19}$

\section{Pasal 21 Undang-Undang} Perlindungan Anak menjelaskan bahwa Pemerintah Daerah berkewajiban dan bertangung jawab untuk menghormati pemenuhan hak anak tanpa membedakan suku, agama, ras, golongan, jenis kelamin, etnik, budaya dan bahasa, status hukum, urutan kelahiran, dan kondisi fisik dan/atau mental. Untuk menjamin pemenuhan Hak Anak Pemerintah Daerah berkewajiban untuk memenuhi, melindungi, dan menghormati Hak Anak, Pemerintah Daerah juga berkewajiban dan bertanggung jawab dalam merumuskan dan

18 Iman Jauhari, "Perbandingan Sistem Hukum Perlindungan Anak Antara Indonesia Dan Malaysia," Jurnal Asy-Syir'ah Volume 47, no. Nomor 2 (2013): h. 612.

19 M. Nasir Djamil, Anak Bukan Untuk Dihukum (Jakarta: Sinar Grafika, 2013), h. 8. melaksanakan kebijakan di bidang penyelenggara perlindungan anak . Untuk menjamin pemenuhan Hak Anak dan melaksanakan kebijakan sebagaimana dimaksud diatas maka, Pemerintah Daerah berkewajiban dan bertanggung jawab untuk melaksanakan dan mendukung kebijakan nasional dalam penyelenggaraan Perlindungan Anak di daerah. Kebijakan ini dapat diwujudkan melalui upaya daerah membangun kabupaten/kota layak Anak. ${ }^{20}$

Pemerintah daerah dalam hal ini berkewajiban membantu tumbuh kembang anak agar menjadi anak yang bisa memikul tanggung jawab. Upaya pemerintah daerah dalam menyelanggarakan pemeliharaan, perawataan dan membantu anak yaitu dengan cara memberikan sekolah dengan gratis. Pemerintah dalam hal ini wajib menyelenggarakan pemeliharaan anak terlantar atau anak jalanan agar bisa terhindar dari kejahataan eksploitasi anak.

Peran yang harus dimainkan pemerintah daerah dalam

20 Laurensius Arliman S Darmini Roza, "Peran Pemerintah Daerah Di Dalam Melindungi Hak Anak Di Indonesia," Masalah - Masalah Huku Jilid 47, no. No. 1 (2018): h. 13. 
menanggulangi eksploitasi trhadap anak adalah mengakomodir kepentingan terbaik anak untuk menyelamatkan kelangsungan hidup, melalui jaminan perlindungan hidup anak-anak Indonesia pada umumnya dan di daerah pada khusunya, baik oleh lembaga legislative, eksekutif, maupun yudikatif di tingkat daerah adalah :

Legeslatif Daerah :

a. Mengagendakan permasalahan anak sebagai perspektif merumuskan kebijakan daerah;

b. Merumuskan peraturan daerah yang lebih kongkrit sesuai dengan karakteristik kondisi anak dan pekerja anak di daerah masing masing;

c. Mengalokasikan anggaran daerah yang proporsional untuk kepentingan terbaik anak dan pekerja anak;

d. Melakukan pengawasan implementasi pemerintahan daerah terhadap peraturan daerah tentang upaya penghapusan pekerja anak;

Eksekutif Daerah :

a. Melakukan identifikasi terhadap bentuk-bentuk terburuk pekerja bagi anak di wilayah masingmasing; b. Melaksanakan peraturan daerah untuk perlindungan bagi anak dan pekerja anak;

c. Malakukan pengawasan dan penindakan bagi pelanggar;

d. Melaporkan kondisi pekerja anak secara periodik kepada publik.

Kota Bengkulu termasuk salah satu wilayah yang mempunyai permasalahan anak yang cukup mengkhawatirkan. Banyaknya anak jalanan di Kota Bengkulu yang ada di jalan raya seperti Simpang Lima, Simpang skip dan tempat-tempat lainnya menunjukkan bahwa ada permasalahan dalam kehidupan anak di Kota Bengkulu. Adanya anak yang bekerja mengikuti orang tuanya dengan berjualan tisu di setiap persimpangan, ada yang mangikuti orang tua dengan mencari barang bekas, mereka bekerja dari siang sampai malam hari dan mereka kehilangan waktu bermain serta istirahat menunjukkan secara nyata pelanggaran terhadap hak anak.

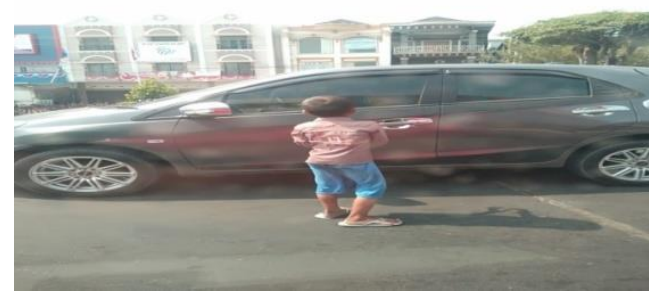


Riri Tri Mayasari dan Mikho Ardinata:

Peranan Pemerintah Daerah Dalam Upaya Penanggulangan Eksploitasi Terhadap Anak Di Kota Bengkulu Berdasarkan Undang-Undang Nomor 23 Tahun 2002 Tentang Perlindungan Anak

Gambar: Seorang anak mengamen di simpang skip Kota Bengkulu

Kanak-kanak adalah usia untuk bermain dan menyerap segala sesuatu. Mereka memiliki respon yang hanya cukup untuk menirukan, maka dari itu kita harus mengajarkan sesuatu yang baik kepada mereka. Mengeksploitasi anak untuk alasan apapun, apalagi alasan ekonomi adalah tindak kejahatan yang dapat dipidanakan. Menurut Undang-Undang ketenagakerjaan No 13 Tahun 2003, pengusaha yang mempekerjakan anak di bawah umur dapat dipidanakan. Akan tetapi, hal tersebut menjadi sesuatu yang ironis. Di tengah himpitan ekonomi yang semakin menghimpit, banyak anak di kota bengkulu yang turut serta menyangga perekonomian keluarganya dengan cara yang bermacam-macam.

Pemerintah daerah Kota Bengkulu dalam menanggulangi eksploitasi terhadap anak dikota bengkulu telah mengeluarkan Peraturan Daerah Kota Bengkulu Nomor 5 Tahun 2016 Tentang Penyelenggaraan Perlindungan Anak. Beserta Peraturan Walikota Nomor 6 tahun 2019 Tentang ketentuan dan Tata Cara Pelaksanaan Perda Nomor 5 Tahun 2016 Tentang Penyelenggaraan Perlindungan Anak. Ini merupakan bentuk upaya pemerintah daerah di kota bengkulu dalam melindungi kepentingan anak, upaya yang dilakukan pemerintah kota Bengkulu selaras dengan pemerintah pusat dalam upaya melindungi anak berdasarkan Undang-Undang 23 Tahun 2002 tentang perlindungan anak. Dalam ketentuan pasal 4 perda nomor 5 tahun 2016 mengatakan : Penyelenggaraan perlindungan anak bertujuan untuk menjamin pemenuhan hak anak atas perlindungan dari kekerasan, perlakuan salah, eksploitasi, dan penelantaran secara sistematis, terintegrasi, dan berkesinambungan. Penyelenggaraan Perlindungan Anak merupakan serangkaian kegiatan yang dilakukan oleh Pemerintah Kota, masyarakat, dan orang tua, yang ditujukan untuk mencegah, mengurangi resiko, dan menangani korban tindakan kekerasan, eksploitasi, perlakuan salah dan penelantaran terhadap anak.

Upaya pencegahan yang dilakukan oleh pemerintah kota Bengkulu sesuai dengan ketentuan peraturan walikota sebagaiman dimaksud dalam Pasal 6 huruf a, meliputi:

a. perumusan kebijakan, program, dan mekanisme tentang pencegahan, pengawasan, pengaduan/pelaporan 
dan pengembangan data masalah perlindungan anak;

b. meningkatkan kesadaran dan sikap masyarakat melalui sosialisasi, edukasi dan informasi mengenai hakhak anak, perlindungan anak, dan pengasuhan anak.

c. meningkatkan kapasitas pelayanan perlindungan anak yang meliputi pengembangan kapasitas kelembagaan dan tenaga penyedia layanan.

d. meningkatkan kemampuan anak untuk mengenali resiko dan bahaya dari situasi atau perbuatan yang dapat menimbulkan kekerasan, eksploitasi, perlakuan salah, dan penelantaran.

Salah satu bentuk peranan pemerintah daerah kota bengkulu untuk menanggulangi eksploitasi terhadap anak seseuai dengan amanat undangundang 45 pasal 34 ayat 1 "Fakir miskin dan anak terlantar di pelihara oleh negara dan di dalam peraturan walikota kota bengkulu nomor 05 tahun 2016 tentang perlindungan anak, dalam ketentuan umum pasal 1 angka 9 eksploitasi terhadap anak adalah setiap perbuataan melibatkan anak dalam kegiataan yang dapat merugikan kesejahteraan dan tumbuh kembang atau membahayakan keselamatan anak dengan tujuan membuat orang lain dapat memperoleh manfaat, ekonomi, seksual, sosial atau juga politik , termasuk bila di dalamnya terdapat pembatasan. Upaya pencegahan : upaya pengembangan kemampuan dan mekanisme pemerintah daerah dan masyarakat dalam menciptakan kondisi yang dapat mencegah terjadinya kekerasaan, perlakuan salah, eksploitasi dan penelantaran, selain peran pemerintah perananan masyarakat dan orang tua sangat di perlukan dalam hal ini kewajiban dan tanggung jawab masyarakat atas perlindungan anak sebagaimana telah diatur dalam ketentuan Pasal 25. Kewajiban dan tanggung jawab masyarakat terhadap perlindungan anak dilaksanakan melalui kegiatan peran masyarakat dalam penyelenggaraan perlindungan anak. Ketentuan Pasal 72 ayat (2) UndangUndang tentang Perlindungan Anak menyebutkan bahwa peran masyarakat dilakukan oleh orang perseorangan, lembaga perlindungan anak, lembaga sosial kemasyarakatan, lembaga swadaya masyarakat, lembaga pendidikan, lembaga keagamaan, badan usaha, dan media massa. Dan pemenuhan tanggung jawaban orang tua dalam ketentuan Pasal 26 UndangUndang tentang Perlindungan Anak mengatur mengenai kewajiban dan tanggung jawab keluarga dan orang tua. 
Riri Tri Mayasari dan Mikho Ardinata:

Peranan Pemerintah Daerah Dalam Upaya Penanggulangan Eksploitasi Terhadap Anak Di Kota Bengkulu Berdasarkan Undang-Undang Nomor 23 Tahun 2002 Tentang Perlindungan Anak

Orang tua berkewajiban dan

bertanggungjawab untuk :

a. mengasuh, memelihara, mendidik, dan melindungi anak;

b. menumbuhkembangkan anak sesuai dengan kemampuan anak, bakan dan minatnya;

c. mencegah terjadinya perkawinan pada usia anak-anak.

d. Memberikan pendidikan karakter dan penanaman budi pekerti pada anak.

\section{Penutup}

Peranan pemerintah daerah dalam penanggulangan eksploitasi terhadap anak di kota bengkulu belum berjalan dengan semsestinya seharusnya dengan adannya perda Nomor 5 tahun 2016 tentang perlindungan anak, dan di perjelas lagi dengan peraturan walikota nomor 6 tahun 2019 berakaitan dengan tata cara pelaksanaan dari perda nomor 5 tahun 2016 tentang perlindungan anak langsung bisa di implementasikan dengan baik dan pemenuhan kewajiban pemerintah daerah dalam melakukan pembinaan baik orang tua maupun anak. Serta peran dari berbagai pihak baik orang tua, masyarakan dan lembaga swadaya menjadi acuan upaya penanggulangan eksploitas terhadap anak di kota bengkulu sesuai dengan UndangUndang nomor 23 tahun 2002 Tentang Perlindungan Anak.
Saran

Saran kepada pemerintah daerah melalui OPD agar mengikuti aturan yang dibuat walikota melalui perda nomor 5 tahun 2016 apa lagi sudah ada peraturan walikota berkaitan dengan tata cara pelaksanaan perda tersebut, sehingga memudah kan OPD untuk mengimplementasikan nya. Salah satu penanggulangan eksploitasi selain peranan pemerintah, juga perlu kesadaran orang tua dan masyarakat bahwa pemenuhan hak anak di jamin oleh undang-undang, jangan mengorbankan masa depan anak hanya karna alasan ekonomi, berikan ruang untuk anak agar mendapatkan pendidikan yang layak.

\section{Pustaka Acuan}

Ajeng Gayatri Octorani Putri, Elly Malihah, Siti Nurbayani K. "Ekploitasi Pekerja Anak Dibawah Umur Sebagai Bentuk Penyimpangan Sosial." Jurnal Sosietas Volume 5, no. No 1 (2002).

Ashshofa, Burhan. Metode Penelitian Hukum. Jakarta: Rineka Cipta, 2004.

Darmini Roza, Laurensius Arliman S. "Peran Pemerintah Daerah Di Dalam Melindungi Hak Anak Di Indonesia." Masalah - Masalah Huku Jilid 47, no. No. 1 (2018).

Djamil, M. Nasir. Anak Bukan Untuk Dihukum. Jakarta: Sinar Grafika, 2013. 
Dkk, Soerjono Soekanto. Penelitian Hukum Normatif: Suatu Tinjauan Singkat. Jakarta: Raja Grafindo Persada, 2012.

Faisal, Sarafiah. Format-Format Penelitian Sosial. Bandung: Raja Grafindo Perkasa, 1999.

Fitriani, Rini. “Anak Dalam Melindungi Dan Memenuhi Hak-Hak Anak.” Jurnal Hukum: Samudra Keadilan 11, no. 2 (2016): 250-258.

Hardius Usman, Nachorowi Djajal. Pekerjaan Anak Di Indonesia. Jakarta: Grasindo, 2004.

Jauhari, Iman. "Perbandingan Sistem Hukum Perlindungan Anak Antara Indonesia Dan Malaysia.” Jurnal AsySyir'ah Volume 47, no. Nomor 2 (2013).

Marzuki, Peter Mahmud. Penelitian

Hukum. Jakarta: Kencana, 2005.

Noeng Muhadjir. Metode Penelitian Kualitatif Edi IV. Yogyakarta: Rake Sarasin, 2000.

Piri, Megalia Tifani. "Perlindungan Hukum Terhadap Tindakan Eksploitasi Anak (Kajian UndangUndang Nomor 23 Tahun 2002.” Lex Administratum Vol.I, no. No.2,AprJun (2013).

Putra, Hendi Sastra. "Peranan Rumah Singgah Al Maun Dalam Memberikan Pendampingan Anak Terlantar Di Kota Bengkulu.” Jurnal
Pemerintahan dan Politik Islam

Volume 5, no. Nomor`1 (2020).

Setyowati, Soemitro. Irma. Aspek Hukum Perlindungan Anak. Jakarta: Bumi Aksara, n.d.

Soeaidy, Sholeh, Zulkhair. Dasar Hukum Perlindungan Anak. Jakarta: Novindo Pustaka Mandiri, 2001.

Soemitro, Ronny Hanitijo. Metode Penelitian Hukum. Semarang: Ghalia Indonesia, 1983. Metode Penelitian Hukum Dan Jurimetri Cetakan Ketiga. Semarang: Ghalia Indonesia, 1988.

Tunggal, Hadi Setia. Konvensi Hak-Hak Anak (Convention on the Rights of the Child). Cetakan ke. Harvarindo, 2000. Ketentuan Umum Pasal 1 Dan 2 UndangUndang 23 Tahun 2002 Tentang Perlindungan Anak, n.d. 